\title{
Homoharringtonine interacts synergistically with bortezomib in NHL cells through MCL-1 and NOXA-dependent mechanisms
}

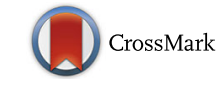

\author{
Tri Nguyen ${ }^{1,5}$, Rebecca Parker ${ }^{1}$, Yu Zhang ${ }^{1}$, Elisa Hawkins ${ }^{1}$, Maciej Kmieciak ${ }^{5}$, William Craun ${ }^{1}$ \\ and Steven Grant ${ }^{1,2,3,4,5^{*}}$ (D)
}

\begin{abstract}
Background: Interactions between the protein synthesis inhibitor homoharringtonine $(\mathrm{HHT})$ and the proteasome inhibitor bortezomib were investigated in DLBCL and mantle cell lymphoma cells (MCL).

Methods: Various DLBCL and MCL cells were exposed to HHT and bortezomib alone or together after which apoptosis and signaling pathway perturbations were monitored by flow cytometry and Western blot analysis. Xenograft mouse models were used to assess tumor growth and animal survival.

Results: HHT and bortezomib co-administration synergistically induced apoptosis in GC-, ABC- and double-hit DLBCL cells. Similar interactions were observed in MCL cells and in primary lymphoma cells. HHT/bortezomib co-administration diminished binding of MCL-1 to both BAK and NOXA. Knock-down of NOXA significantly diminished lethality whereas MCL-1 knock-down or ectopic NOXA expression increased cell death. Notably, HHT/bortezomib lethality was dramatically reduced in BAK knockout or knockdown cells. Finally, HHT/bortezomib co-administration significantly improved survival compared to single agents in GC- and ABC-xenograft models while exhibiting little toxicity.

Conclusions: These findings indicate that HHT and bortezomib cooperate to kill DLBCL and MCL cells through a process involving MCL-1 down-regulation, NOXA up-regulation, and BAK activation. They also suggest that a strategy combining HHT with bortezomib warrants attention in DLBCL and MCL.
\end{abstract}

Keywords: Homoharringtonine (Omacataxine), Bortezomib, Mantle cell lymphoma, Diffuse large B-cell lymphoma

\section{Background}

Diffuse large B-cell lymphoma (DLBCL) is a form of non-Hodgkin's lymphoma (NHL) that afflicts approximately 23.000 patients/year in the US [1]. Despite recent advances such as the introduction of effective new targeted therapies (e.g., ibrutinib) [2] and an improved understanding of the molecular pathogenesis of this disorder [3], patients with relapsed/refractory disease have a dismal prognosis. In addition, outcomes in certain genetic sub-types e.g., $\mathrm{ABC}$ (activated B-cell) versus GC (germinal center) DLBCL are inferior $[4,5]$, and patients

\footnotetext{
* Correspondence: steven.grant@vcuhealth.org

${ }^{1}$ Division of Hematology/Oncology, Virginia Commonwealth University Richmond, Room 229 Goodwin Research Building, 401 College Street, Richmond, VA 23229, USA

${ }^{2}$ Palliative Care, Virginia Commonwealth University Richmond, Richmond, VA, USA

Full list of author information is available at the end of the article
}

with double- (or triple-) hit lymphomas displaying increased expression of BCL-2, BCL-6, and/or c-Myc do particularly poorly [6]. Mantle cell lymphoma (MCL) is an aggressive form of lymphoma which also carries a relatively poor prognosis [7]. Consequently, newer and more effective treatment strategies are urgently needed for these diseases.

Bortezomib is an inhibitor of the $20 \mathrm{~S}$ proteasome, and by extension, the ubiquitin-proteasome system (UPS), which is responsible for degradation of diverse cellular proteins and maintenance of protein homeostasis [8]. It is approved for use in multiple myeloma as well as in MCL, in which single-agent activity is 30\% [9]. Addition of bortezomib to standard chemotherapy may also be of benefit in certain DLBCL sub-types e.g., ABC-DLBCL [10]. The mechanism of resistance of neoplastic cells e.g., myeloma to bortezomib is not known with certainty, but

(c) The Author(s). 2018 Open Access This article is distributed under the terms of the Creative Commons Attribution 4.0 International License (http://creativecommons.org/licenses/by/4.0/), which permits unrestricted use, distribution, and 
accumulation of anti-apoptotic proteins e.g., MCL-1 due to interference with degradation has been implicated [11].

Homoharringtonine (HHT or omacetaxine mepesuuccinate, Synribo ${ }^{\circ}$ ) is an inhibitor of translation elongation and protein synthesis $[12,13]$. It is a semisynthetic derivative omacetaxine mepesuccinate which has been approved for the treatment of patients with chronic myelogenous leukemia (CML) resistant to tyrosine kinase inhibitors $[14,15]$. Its ability to disrupt protein synthesis leads to down-regulation of short-lived proteins, including MCL-1 [16]. Indeed, the lethal effects of HHT in various malignant hematopoietic cells e.g., leukemia has been related to diminished expression of this protein $[12,17,18]$.

The potential role of MCL- 1 in conferring bortezomib resistance $[11,19]$ supports the use of HHT in conjunction with this agent. In fact, studies in multiple myeloma cells indicate that HHT potentiates bortezomib activity through multiple mechanisms, including MCL-1 downregulation and interference with stromal cell factors, among others [20]. Currently, no information exists regarding whether HHT might enhance bortezomib activity in NHL cells, and the mechanisms that may underlie such a phenomenon. Here we report that HHT synergistically enhances the activity of bortezomib against diverse lymphoma cell types (including primary and double-hit DLBCL cells) both in vitro and in vivo through mechanisms involving MCL-1 down-regulation, NOXA up-regulation, and activation of BAK. Together, these findings raise the possibility of combining HHT and bortezomib in the setting of NHL.

\section{Methods}

Cells

All cell lines were kindly provided or purchased and cultured as described previously [21].

\section{Immunoblot and immunoprecipitation}

Western blot analysis was carried out as previously described [21, 22]. Primary antibodies used in these studies were: cleaved PARP, cleaved caspase-3, BCL-XL, BIM (Cell Signaling Technology, Danvers, MA), MCL-1 (BD Biosciences, San Jose, CA), $\alpha$-tubulin (EMD Millipore, Billerica, MA), BAX (N20), BAK (G23), actin (SigmaAldrich, St. Louis, MO), NOXA (Enzo Life Sciences, Farmingdale, NY).

\section{Plasmids and transfection}

Knockdown MCL-1 and NOXA plasmids were purchased from Dharmacon (Open Biosystem). NOXA/Flag plasmid was kindly provided by Dr. Harada [23]. Luciferase or scrambled shRNA/pLKO.1 was used as control. Lentivirus production was generated using Lipofectamine 3000 (Invitrogen, ThermoFisher Scientific, NJ) following the manufacturer's protocol.

\section{Reagents}

Homoharringtonine (Omacetaxine ${ }^{\circ}$ ) was provided by Teva Pharmaceutical Industries Ltd. Bortezomib was purchased from Chemietek (Indianapolis). BOC-D-fmk was purchased from Abcam. All agents were formulated in DMSO and stocked in $-80{ }^{\circ} \mathrm{C}$ for in vitro use.

\section{Quantitative real-time PCR}

Quantitative real-time PCR (qPCR) analysis using TaqMan gene expression assays and a 7900HT real-time PCR system (Applied Biosystems, Foster City, CA) was performed to quantify mRNA levels of human MCL-1. Briefly, total RNA was isolated by using TRIzol reagent (Invitrogen, Carlsbad, CA) according to the manufacturer's instructions. Genomic DNA was digested with DNase I (amplification grade; Invitrogen). cDNA was synthesized from $1 \mu \mathrm{g}$ of total RNA by using a High Capacity cDNA reverse transcription kit (Applied Biosystems). One microliters of cDNA was employed for qPCR assays (TaqMan gene expression assays). Assay identification numbers for MCL-1 were Hs03043899_m1. References for quantitation were human $\beta$-actin and glyceraldehyde-3phosphate dehydrogenase (GAPDH) (Applied Biosystems). Data were analyzed by using SDS 2.3 software.

\section{In vivo studies}

NOD/SCID- $\gamma$ mice were subcutaneously injected in the flank with $10 \times 10^{6}$ luciferase-expressing U2932 or SU-DHL4 cells. Tumor volume was followed and measured with calipers using the following formula: tumor volume $\left(\mathrm{mm}^{3}\right)=$ length $(\mathrm{mm}) \times$ width $(\mathrm{mm})^{2} / 2$. Omacetaxine $(1 \mathrm{mg} / \mathrm{kg}, 5$ days a weeks) and bortezomib $(0.75 \mathrm{mg} / \mathrm{kg}$, twice a week) was administered via intraperitoneal (i.p.). Control animals were injected with equal volumes of vehicle.

Mice were monitored for tumour growth with caliper and the imaging system by IVIS 200 (Xenogen Corporation, Alameda, CA).

\section{Cell growth and viability, assessment of apoptosis and flow cytometry, collection and processing of primary normal $\mathrm{CD}_{3} 4^{+}$, lymphoma patient cells and statistical analysis}

All procedures and experiments were followed and performed as previously described in detail $[21,22,24]$.

\section{Results}

Co-administration (48 h) of HHT (5-40 nM) with bortezomib (1-5 nM) in diverse NHL lines e.g., SU-DHL-16, SU-DHL-4, SU-DHL-8 (GC), U2932, TMD8, HBL-1 $(\mathrm{ABC})$, including double-hit (OCI-LY18, Carnaval) resulted in a pronounced increase in apoptosis (Fig. 1a). Dose-response studies in SU-DHL16 (GC) cells revealed significant increases in cell death at HHT and 

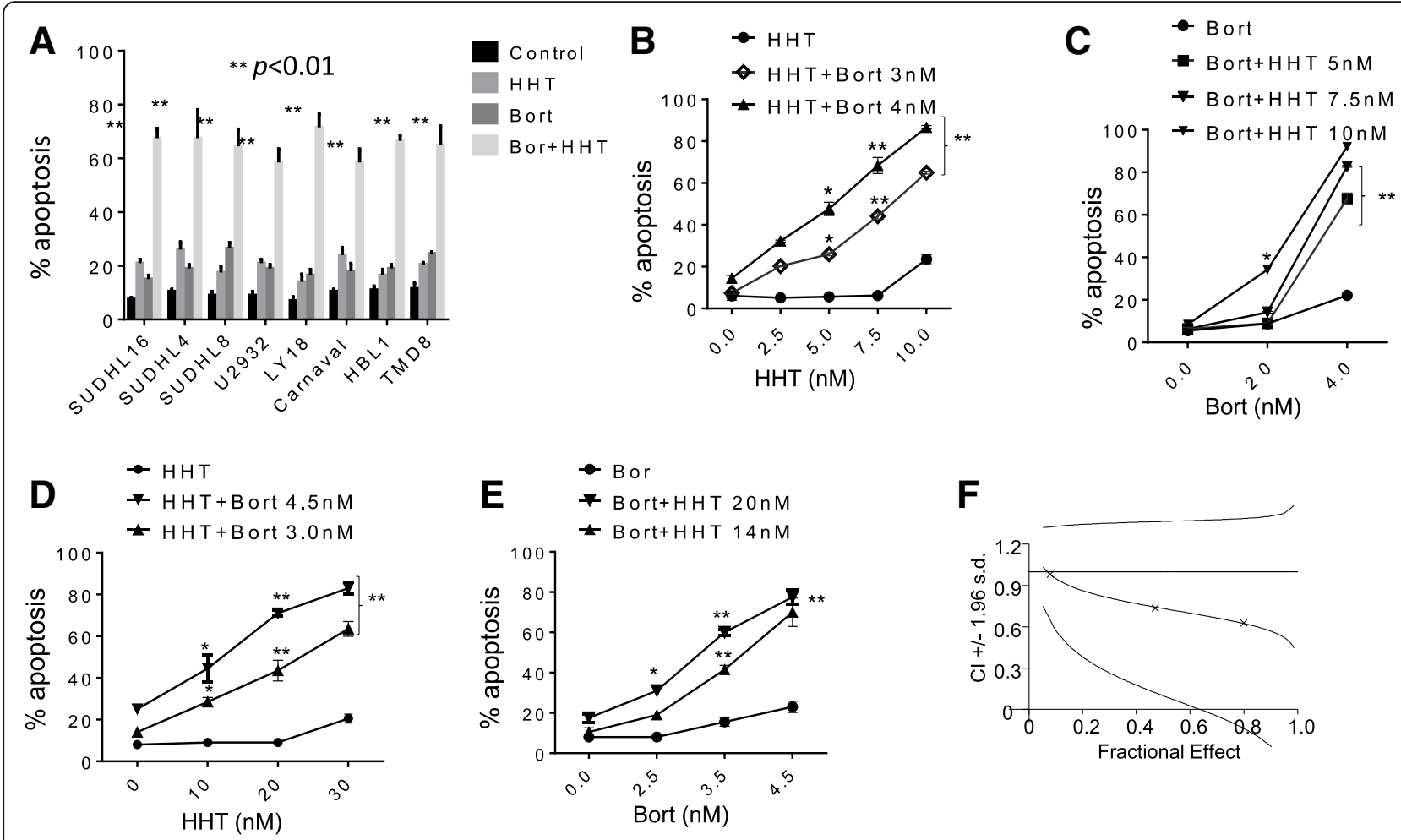

$\mathbf{F}$
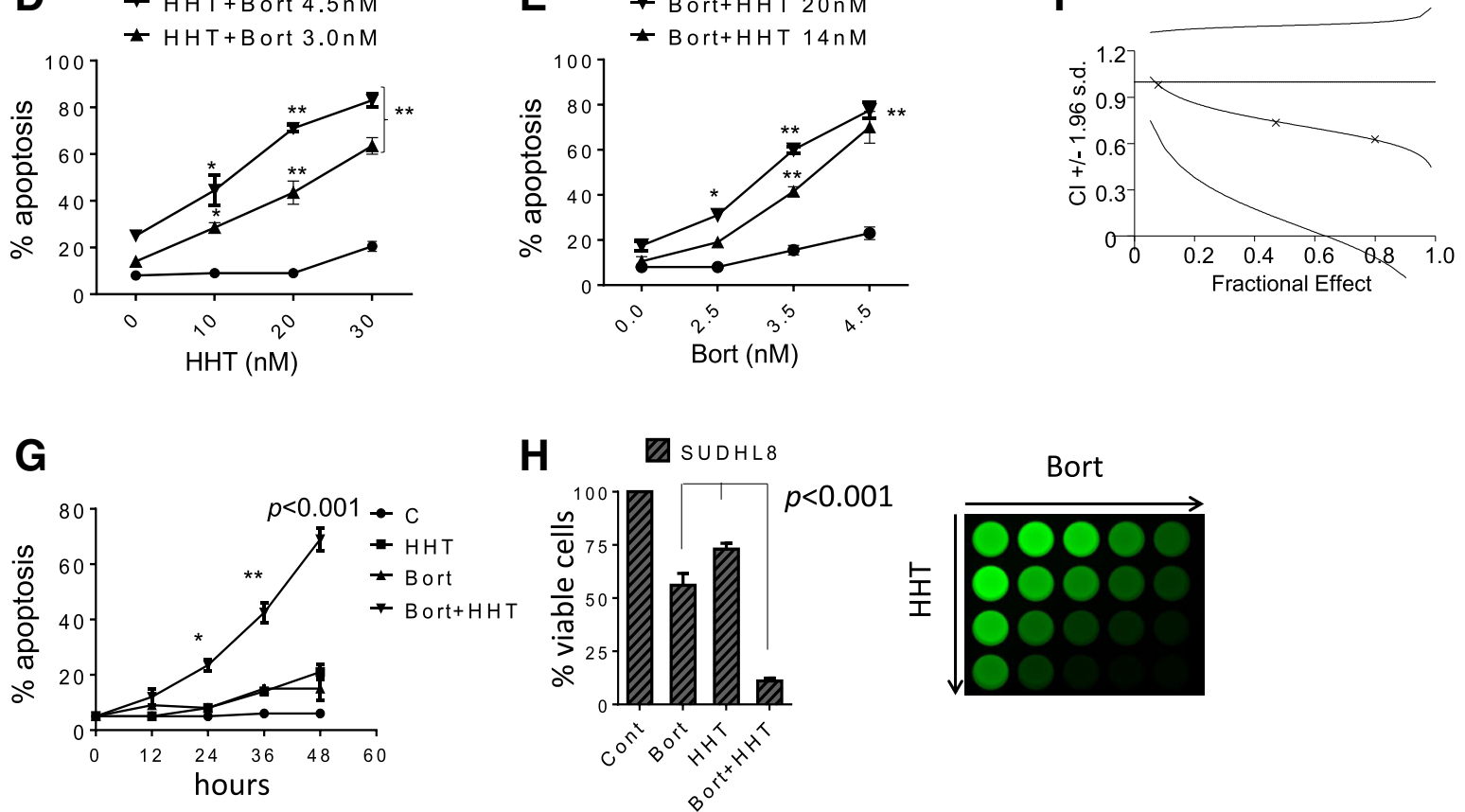

Fig. 1 HHT dramatically increases bortezomib lethality and inhibits cell growth in DLBCL cells. a Various NHL cell lines SU-DHL16, SU-DHL4, SU-DHL8 (GC subtype), HBL-1, U2932 (ABC-subtype), OCI-LY18, Carnaval (double-hit) were exposed to HHT (10, 15, 12, 15, 30, 10, 10 nmol/L respectively) and bortezomib $\left(1.5,4,2.5,2,4.5,3,2.5 \mathrm{nmol} / \mathrm{L}\right.$ respectively) alone or together for $48 \mathrm{~h}$, after which cell death was assessed by $7-\mathrm{AAD} .{ }^{*} p<0.05,{ }^{* *} p<0.01$, significantly greater than values for single agent treatment. For these and subsequent studies, values represent the means \pm S.D. for experiments performed in triplicate on at least 3 separate occasions. b SU-DHL16 cells were exposed to the indicated concentration of HHT in the presence or absence of bortezomib for $48 \mathrm{~h}$, after which cell death was assessed by 7-AAD. c SU-DHL16 cells were exposed to the indicated concentration of bortezomib in the presence or absence of HHT for $48 \mathrm{~h}$, after which cell death was assessed by 7-AAD. $\mathbf{d}$ SU-DHL8 cells were exposed to the indicated concentration of HHT in the presence or absence of bortezomib for $48 \mathrm{~h}$, after which cell death was assessed by 7-AAD. e SU-DHL8 cells were exposed to the indicated concentration of bortezomib in the presence or absence of HHT for $48 \mathrm{~h}$, after which cell death was assessed by 7-AAD. ${ }^{*} p<0.05,{ }^{* *} p<0.01$, significantly greater than values for single agent treatment. $\mathbf{f} S \mathrm{SU}-\mathrm{DHL}-8$ cells were treated with a range of HHT and bortezomib concentrations administered at a fixed ratio. At the end of $48 \mathrm{~h}$, the percentage of cell death was determined by monitoring $7 \mathrm{AAD}^{+}$cells. Cl values were determined in relation to the fractional effect by using Calcusyn software. Cl values less than 1.0 correspond to synergistic interactions. g SU-DHL8 cells were treated with HHT $(12 \mathrm{nmol} / \mathrm{L})$ or bortezomib $(3.5 \mathrm{nmol} / \mathrm{L})$ individually or in combination for the indicated intervals, after which the extent of cell death was determined by 7-AAD uptake and flow cytometry. $\mathbf{h}$ Cells were exposed to HHT and bortezomib as described above alone or together for $48 \mathrm{~h}$, after which cells were enumerated by hemocytometer (left panel, $p<0.001$, significantly greater than values for single agent treatment). SU-DHL-8 were exposed to increasing concentrations of HHT and bortezomib, after which cell growth and viability were evaluated using the CellTiter-Glo Luminescent assay (right panel)

bortezomib concentrations as low as $7.5 \mathrm{nM}$ or $4 \mathrm{nM}$ respectively (Fig. 1b-c). Similarly, SU-DHL8 cells showed significant increases in cell death at HHT and bortezomib concentrations as low as $20 \mathrm{nM}$ or $3.5 \mathrm{nM}$ respectively (Fig. 1d-e). Median Dose Effect analysis yielded CI values $<1.0$, denoting synergistic interactions (Fig. 1f). Time 
course studies showed that significant increases in cell death were observed at $24 \mathrm{~h}$ of co-incubation, and increased further over the ensuing $24 \mathrm{~h}$ (Fig. 1g). Similar results were observed in SU-DHL4 (Additional file 1A) and double-hit OCI-LY18 DLBCL cells; Additional file 1B-E). Finally, equivalent results were obtained when viable cell number and MTT assays were monitored (Fig. 1f).

Parallel studies were performed in mantle cell lymphoma cells, where co-administration (48 h) of HHT and bortezomib resulted in marked increase in apoptosis in $5 \mathrm{MCL}$ lines (Fig. 2a). Dose responses in Jeko1 cells were similar to those obtained in DLBCL cells i.e., significant increases in cell death were observed with HHT concentrations $\geq 10 \mathrm{nM}$ and bortezomib concentrations $\geq 1.8 \mathrm{nM}$ (Fig. 2b-c). Similar results were observed in NCEB cells (Additional file 1-F). Median Dose Effect analysis confirmed synergistic interactions in Jeko (Fig. 1d). Finally, studies performed in primary cells obtained from peripheral blood cells of 2 patients (\#1 double-hit DLBCL; \#2 follicular lymphoma) revealed significant increases in cell death with concomitant HHT/bortezomib exposure compared to single-agent treatment (24 h; Fig. 2e). Similar exposures minimally induced cell death in normal CD34 ${ }^{+}$cells (Fig. 2f).

Western blot analysis was employed to monitor expression of BCL-2 family members in response to the HHT/bortezomib regimen. Combined treatment $(20 \mathrm{~h})$ of GC-DLBCL (SU-DHL16), double-hit DLBCL cells (OCI-LY18, Carnaval) or ABC-DLBCL (HBL-1) resulted in increased caspase- 3 cleavage but little change in the expression of BCL2, BCL-xL, or BIM (Fig. 3a). Notably, HHT in combination with bortezomib resulted in a further reduction in levels of MCL-1. In addition, bortezomib alone or with HHT sharply increased expression of the pro-apoptotic protein NOXA. Similar results were

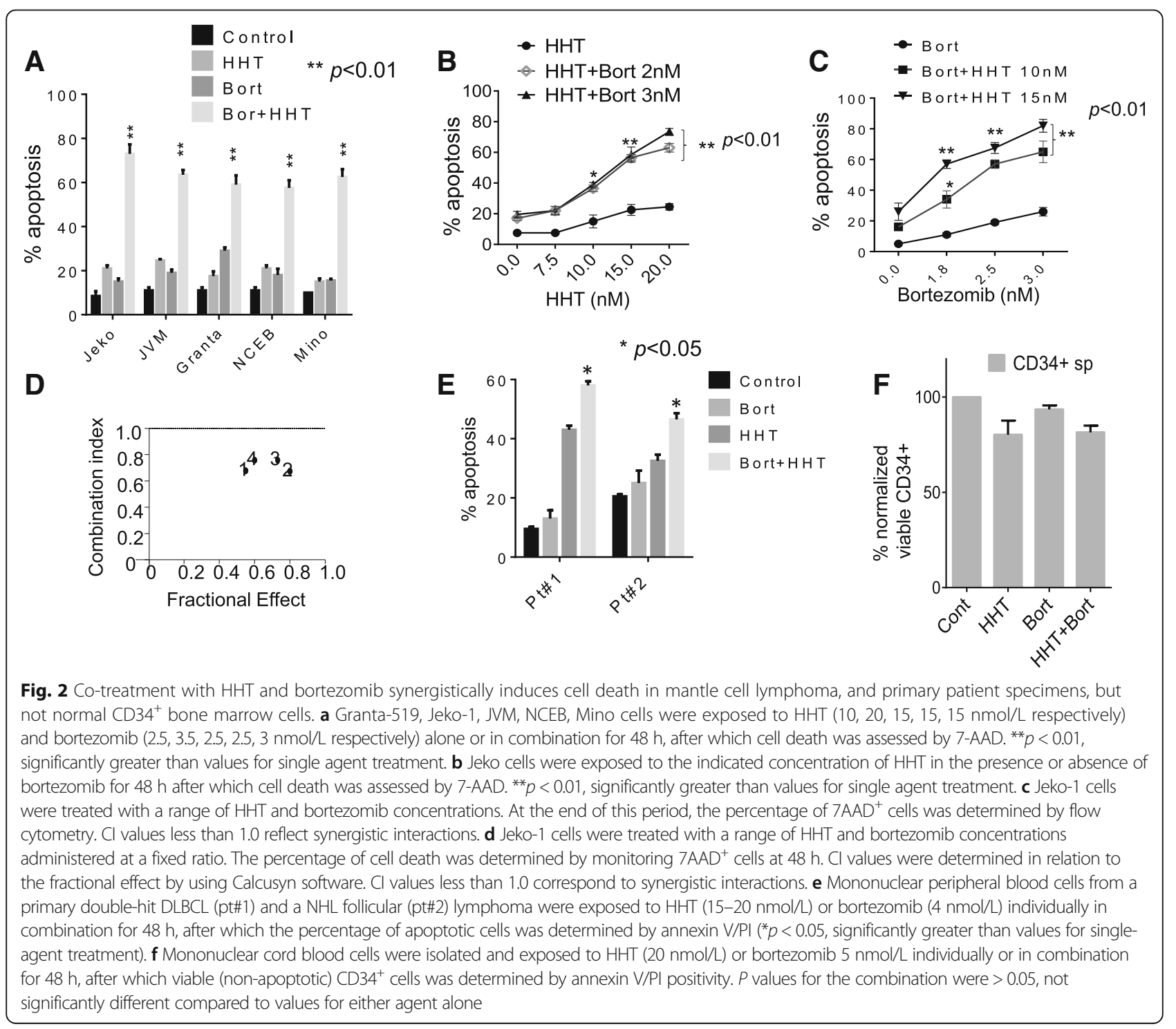




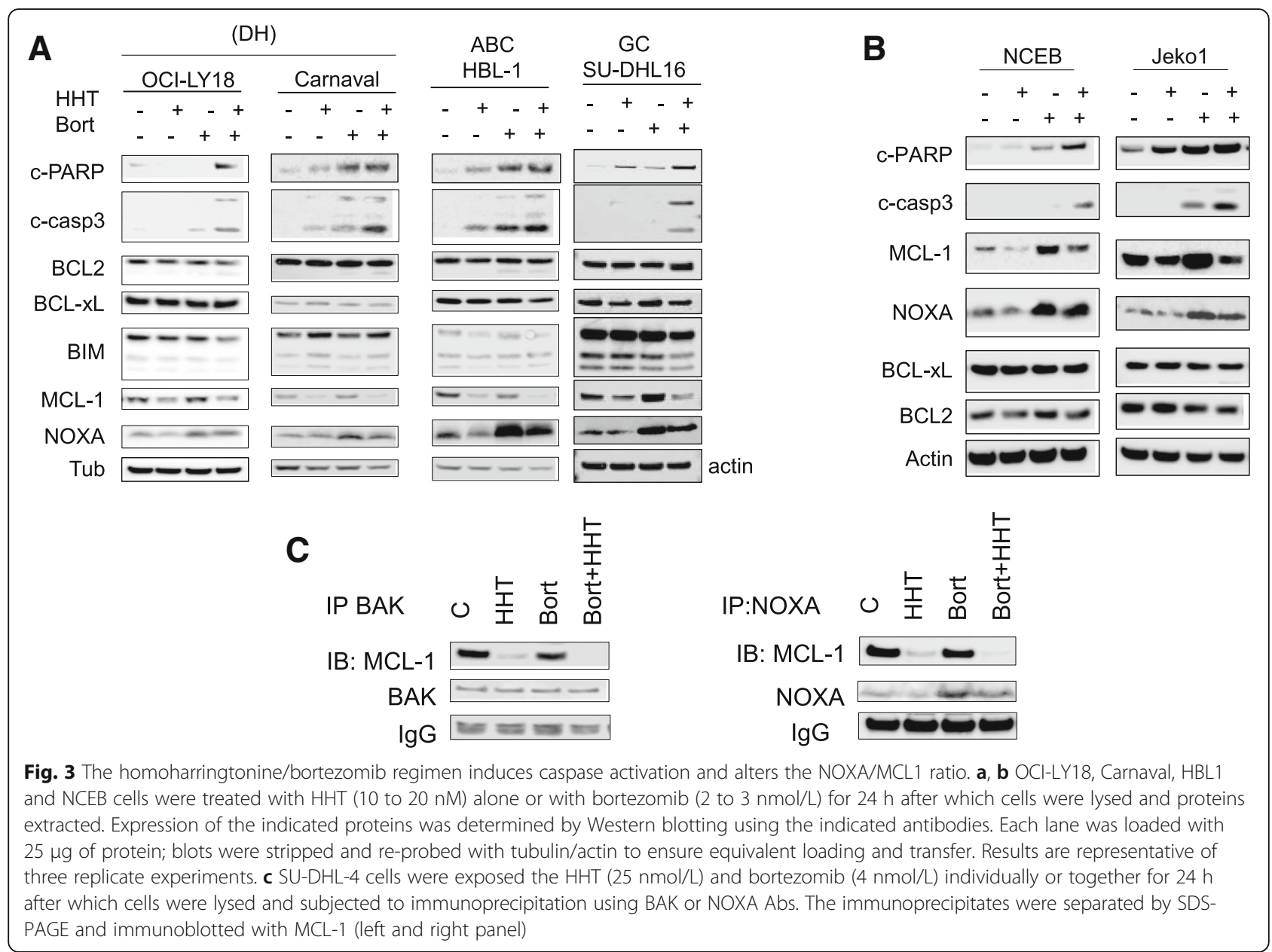

observed in the case of Jeko-1 and NCEB mantle cell lymphoma cells in which bortezomib alone clearly up-regulated MCL-1 expression, and this effect was attenuated by HHT (Fig. 3b). To determine whether any of these perturbations were secondary to caspase-mediated degradation, OCI-LY18 and Carnaval cells were incubated with $\mathrm{HHT}+$ Bort in the presence or absence of the broad-spectrum caspase inhibitor BOC-D-fmk $5 \mu \mathrm{mol} / \mathrm{L}$. Addition of BOC-D-fmk did not change HHT/Bort-mediated down-regulation of MCL-1 (Additional file 2). These findings suggest that HHT/Bort-induced changes in signaling proteins in all likelihood do not represent a consequence of cell death. Finally, immunoprecipitation studies in SU-DHL-4 cells revealed that co-administration of HHT and bortezomib diminished binding of MCL-1 to BAK and NOXA (Fig. 3c).

Studies were then undertaken to characterize the basis by which HHT down-regulated MCL-1 expression. As shown in Additional file 3A, HHT alone reduced MCL-1 expression by $8 \mathrm{~h}$ in both SU-DHL4 and 16 cells. However, RT-PCR analysis revealed that HHT induced, if anything, an increase in MCL-1 mRNA (Additional file 3B). In addition, co-administration of the transcriptional inhibitor actinomycin resulted in a further decline in MCL-1 levels (Additional file 3C), suggesting an alternative mechanism of action. In contrast, the translational inhibitor cyclohexamide had little effect on HHT-mediated MCL-1 down-regulation (Additional file 3D), consistent with a common mechanism of action. Together, these findings argue that HHT acts to down-regulate MCL-1 in these cells through a post-transcriptional mechanism.

The role of the pro-apoptotic multi-domain proteins BAX and BAK on responses to the HHT/bortezomib regimen were then examined. While exposure of OCI-LY18 cells to HHT or bortezomib individually had little effect on BAX or BAK conformational change, combined treatment robustly increased activation of both (Fig. 4a). Furthermore, shRNA knock-down of BAX in U2932 cells modestly but significantly diminished HHT/bortezomib lethality whereas BAK knock-down sharply reduced cell killing (Fig. 4b). Parallel studies performed in BAK, BAX and double-knock-out (DKO) MEF cells revealed that 


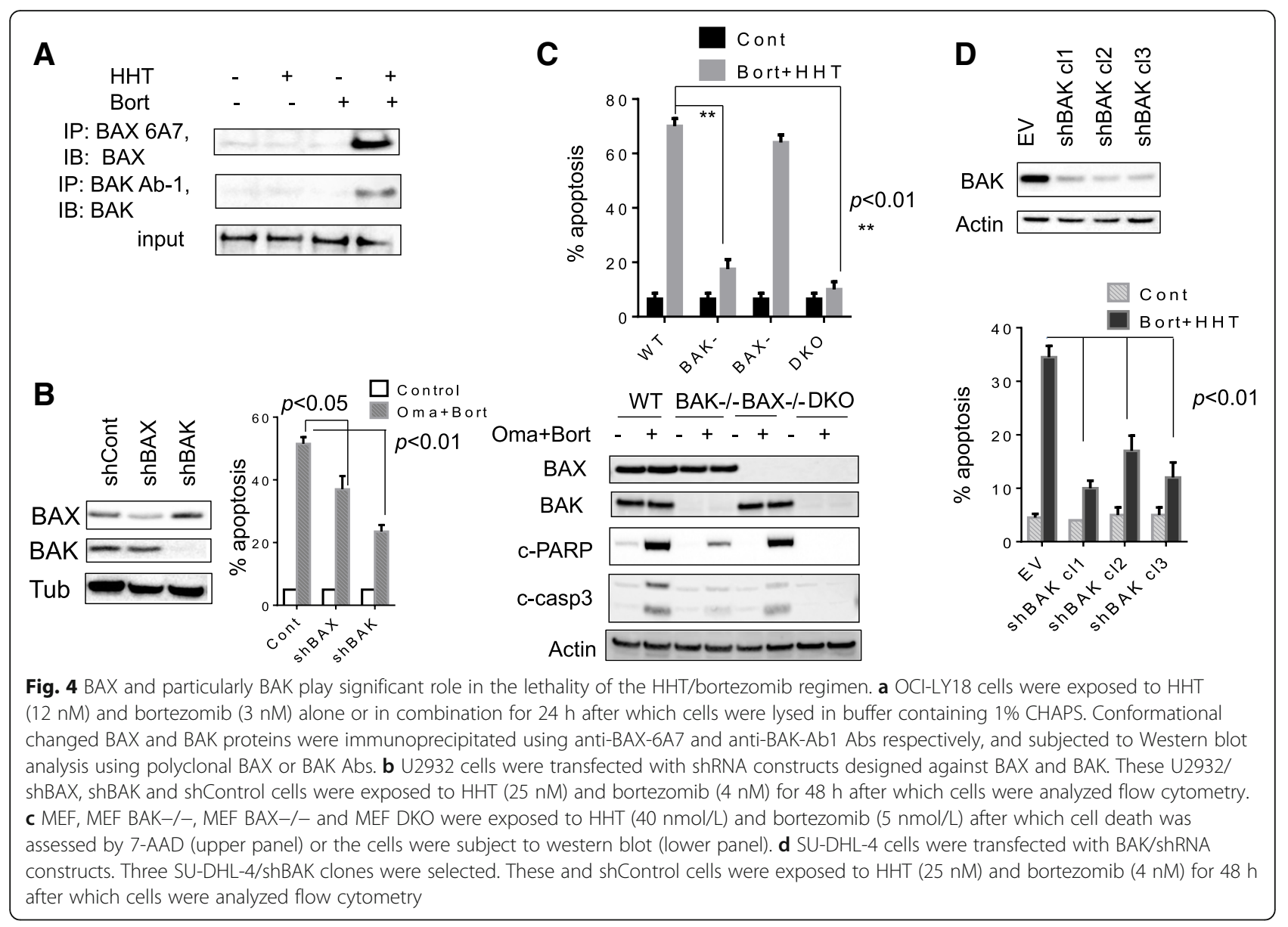

BAK KO or DKO dramatically reduced lethality whereas BAX KO had little effect (Fig. 4c, upper panel). Consistent results were obtained when PARP and caspase- 3 cleavage were monitored (Fig. 4c, lower panel). Finally, shRNA knock-down of BAK in SU-DHL-4 cells (Fig. 4d, upper panel) significantly diminished HHT/bortezomib lethality $(p<0.01$; Fig. $4 d$, lower panel). Together, these findings argue that BAK activation plays a significant functional role in HHT/bortezomib lethality.

To evaluate the functional significance of MCL-1 down-regulation in HHT/bortezomib lethality, SU-DHL-4 MCL-1 shRNA knock-down clones were generated (shMCL-1 cl1 and cl2; Fig. 5a, left panel). These clones were significantly more sensitive than empty-vector controls to bortezomib-induced apoptosis (Fig. 5a, middle panel) and PARP/caspase-3 cleavage (Fig. 5a, right panel). Similar results were obtained in SU-DHL-16 cells in which MCL-1 was knocked down (Fig. 5b). These findings argue that MCL-1 down-regulation by HHT is likely to increase bortezomib lethality.

To assess the impact of NOXA up-regulation in HHT/ bortezomib activity, SU-DHL-16 cells were engineered to over-express NOXA (Fig. 5c, left panel). Notably, each of the three over-expressing clones was significantly more sensitive to HHT than empty-vector controls (Fig. 5c, middle and right panels). Conversely, NOXA shRNA knock-down cells were significantly less sensitive to HHT-induced apoptosis than their empty-vector counterparts (Fig. 5d).

Finally, the in vivo activity of the HHT/bortezomib regimen was evaluated in two xenograft models. Co-administration of HHT ( $1 \mathrm{mg} / \mathrm{kg} 5 \mathrm{~d} / \mathrm{wk})$ and bortezomib $(0.75 \mathrm{mg} / \mathrm{kg} 2 \times / \mathrm{wk})$ reduced tumor growth and significantly increased survival in mice inoculated in the flank with SU-DHL-4 cells $(p<0.05)$ compared to single-agent treatment (Fig. 6a-b). Similar results were obtained in mice inoculated with double-hit U2932 cells (survival significantly greater than with single agents; $p<0.02$; Fig. $6 c-d)$. In neither model did the regimen induce significant weight loss (e.g., > 10\%; Additional file 4) or other signs of toxicity.

\section{Discussion}

The results of this study indicate that the translational inhibitor HHT interacts synergistically with bortezomib to induce apoptosis in vitro in diverse DLBCL and MCL types, and that the regimen is also effective in the in vivo setting. The mechanisms by which these agents interact 


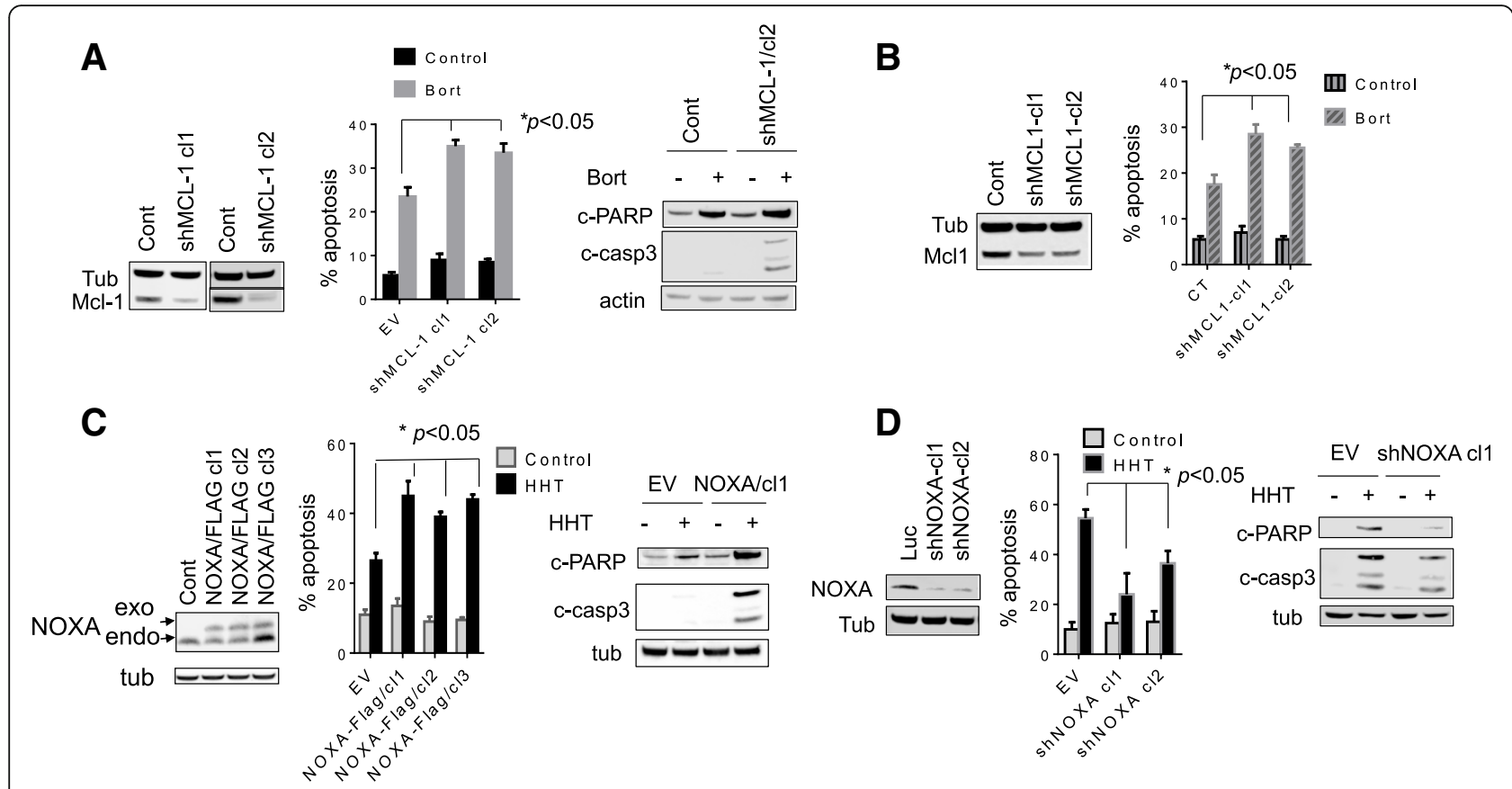

Fig. 5 Genetic inhibition of MCL-1 or overexpression of NOXA renders cells significantly more sensitive to bortezomib. a SU-DHL-4 cells were transfected with shRNA constructs designed against MCL-1. Two clones of shRNA MCL-1 were selected. These 2 clones of SU-DHL-4/shMCL1 and shControl cells were exposed to bortezomib $(4 \mathrm{nM})$ for $48 \mathrm{~h}$ after which cells were analyzed by flow cytometry and western blot. b Similarly, SU-DHL-16 cells were transfected with shRNA constructs designed against MCL-1. SU-DHL-16/shMCL1 and shControl cells were exposed to bortezomib $(1.5 \mathrm{nM})$ for $48 \mathrm{~h}$ after which cells were analyzed flow cytometry and Western blot. c SU-DHL-16 cells were transfected with NOXAVFlag constructs. Three clones with overexpression of NOXA were selected. These clones were exposed to HHT (10 nM) for $48 \mathrm{~h}$ then analyzed by flow cytometry. $\mathbf{d}$ SU-DHL-16 cells were transfected with shNOXA constructs. Two clones with knockdown of NOXA were selected. These clones were exposed to HHT (10 nM) for $48 \mathrm{~h}$ then analyzed by flow cytometry

are likely to be multi-factorial, and appear to involve down-regulation of MCL-1, up-regulation of NOXA, and activation of BAK. The bulk of pre-clinical data related to HHT involves CML models [13, 14], a disease for which this agent is approved in patients with TKI-resistant disease [15]. Recently, studies have suggested that HHT may enhance the lethality of bortezomib in multiple myeloma cells through mechanisms involving inactivation of AKT and NF-kB [20]. Reports of HHT in NHL models are very limited, although one study revealed that HHT lowered the threshold for apoptosis in a sub-set of DLBLC cells exposed to the BH3-mimetic and Bcl-2 antagonist venetoclax [25]. To the best of our knowledge, this represents the first description of HHT/bortezomib synergism in DLBCL and MCL models, diseases in which bortezomib may also play a useful role $[9,26]$.

It is likely that down-regulation of MCL-1 contributes to the observed interactions between bortezomib and HHT. In contrast to BCL-2, MCL-1 is a relatively shortlived protein, and interventions that block its synthesis e.g., transcriptional antagonists that inhibit CDK9/ pTEFb trigger its down-regulation [27-29]. Analogously, inhibitors of translation have also been shown to diminish MCL-1 abundance [12, 30]. In this regard, HHT has been shown to down-regulate MCL-1 in human acute and chronic myeloid leukemia cells [13, 31], chronic lymphocytic leukemia cells [12], and MM cells [20]. The present results indicate that similar events occur in DLBCL and MCL cells. Notably, in addition to its effects on the proteasome and disruption of protein homeostasis, proteasome inhibitors such as bortezomib can induce cell death by preventing the down-regulation of pro-apoptotic proteins e.g., p53 [32, 33]. However, they may also spare certain anti-apoptotic proteins e.g., MCL-1, potentially leading to drug resistance [11]. The observation that shRNA knock-down of MCL-1 significantly increased bortezomib lethality argues that HHT-mediated MCL-1 down-regulation contributed functionally to the activity of this regimen.

The present results argue that NOXA up-regulation by bortezomib also plays a significant functional role in NHL cell death triggered by the HHT/bortezomib regimen. The ability of bortezomib to induce NOXA, contributing to cell death, has been described in several hematopoietic cell types, including CLL [34], MCL [35], and multiple myeloma cells [36]. Of note, NOXA has been implicated in destabilization of MCL-1 [37], raising the possibility of involvement of an amplification loop in HHT/ 


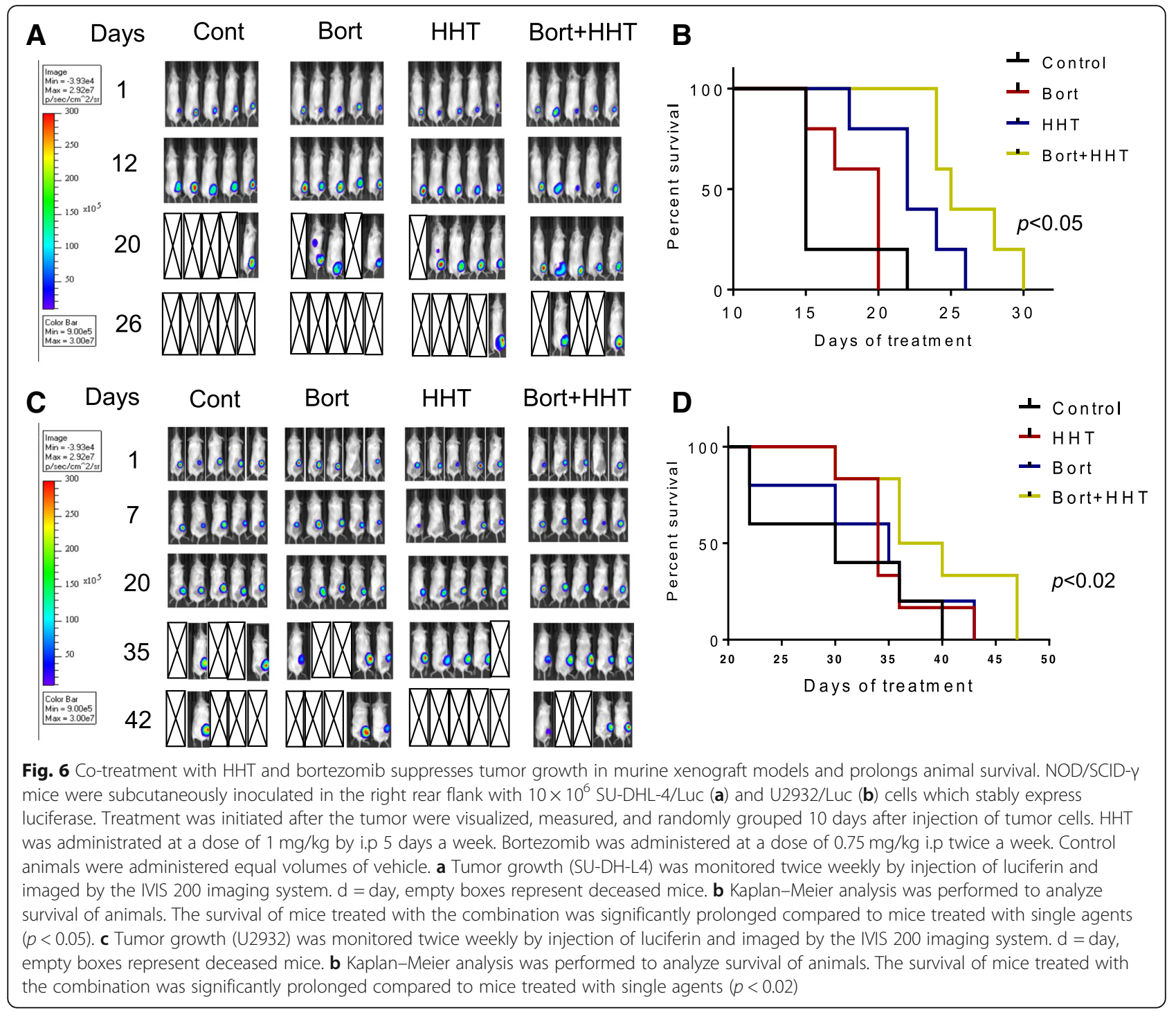

bortezomib interactions. Additionally, co-administration of HHT markedly diminished the amount of MCL-1 coimmunoprecipitating with NOXA, potentially promoting NOXA pro-apoptotic actions [38, 39]. Whether this phenomenon reflects MCL-1 down-regulation or other as yet to be determined actions of HHT remains to be determined. In any case, the finding that enforced NOXA expression significantly increased and shRNA NOXA knockdown significantly reduced HHT lethality in DLBCL cells strongly implicates NOXA up-regulation in HHT/bortezomib synergism.

While co-administration of HHT and bortezomib induced conformational change/activation of the multi-domain pro-apoptotic proteins BAX and BAK, several lines of evidence argue that BAK activation was the primary basis for HHT/bortezomib lethality. In this context, both BAK and NOXA have been identified as critical determinants of bortezomib lethality in mesothelioma cells [40]. However,
HHT/bortezomib lethality was minimally affected in BAX MEF KO cells, whereas it was essentially abrogated in their BAK KO counterparts. Moreover, BAX knock-down in DLBCL cells only modestly diminished HHT/bortezomib lethality, whereas BAK knock-down had a significantly greater effect. Of note, BAK is tethered and inactivated by MCL-1 and BAK can be activated by NOXA [41], raising the possibility that MCL-1 down-regulation and NOXA up-regulation cooperate to activate BAK and subsequently mitochondrial apoptosis.

The finding that ABC- and GC-type DLBCL cells were equally sensitive to the $\mathrm{HHT} /$ bortezomib regimen could reflect multiple factors, including the lack of NF-kBdependent mechanisms underlying interactions between these agents (e.g., MCL-1 down-regulation). The regimen was also effective against double-hit DLBCL models characterized by c-Myc and Bcl-2 overepression, and associated with markedly inferior outcomes in the clinic [4]. 
Finally, the regimen was active against MCL, a disease for which curative therapy is generally lacking and in which single-agent bortezomib has been approved [9]. Significantly, each of these cell types was susceptible to regimens employing very low HHT and bortezomib concentrations (e.g., low $\mathrm{nM}$ ), easily achieved in the plasma of patients receiving these agents [42]. Finally, the observation that the HHT/bortezomib regimen was well tolerated in two DLBCL xenograft models while significantly prolonging survival compared to single-agent administration is noteworthy.

\section{Conclusions}

These findings indicate that HHT and bortezomib synergistically kill DLBCL and MCL cells through a process involving MCL-1 down-regulation, NOXA up-regulation, and BAK activation. The HHT/bortezomib regimen also significantly prolonged survival in DLBCL xenograft models compared to single-agent administeration. These findings argue that such a regimen warrants consideration in patients with high-risk, aggressive forms of DLBCL for whom satisfactory therapeutic options are lacking. Efforts to explore this possibility are underway.

\section{Additional files}

Additional file 1: HHT dramatically increases bortezomib lethality and inhibits cell growth in DLBCL cells. A) SU-DHL4 cells were exposed to the indicated concentration of HHT in the presence or absence of $4 \mathrm{nM}$ bortezomib for $48 \mathrm{~h}$, after which cell death was assessed by 7-AAD. B) $\mathrm{OCI}-\mathrm{LY} 18$ cells were exposed to the indicated concentration of HHT in the presence or absence of bortezomib for $48 \mathrm{~h}$, after which cell death was assessed by 7-AAD. C) OCI-LY18 cells were exposed to the indicated concentration of bortezomib in the presence or absence of HHT for $48 \mathrm{~h}$, after which cell death was assessed by 7-AAD. D) OCI-LY18 cells were treated with HHT $(12 \mathrm{nmol} / \mathrm{L})$ or bortezomib (3 $\mathrm{nmol} / \mathrm{L})$ individually or in combination for the indicated intervals, after which the extent of cell death was determined by 7-AAD uptake and flow cytometry. E) OCI-LY18 cells were treated with a range of $\mathrm{HHT}$ and bortezomib concentrations administered at a fixed ratio. At the end of $48 \mathrm{~h}$, the percentage of cell death was determined by monitoring $7 \mathrm{AAD}^{+}$cells. Cl values were determined in relation to the fractional effect by using Calcusyn software. Cl values less than 1.0 correspond to synergistic interactions. F) NCEB cells were exposed to the indicated concentration of $\mathrm{HHT}$ in the presence or absence of bortezomib for $48 \mathrm{~h}$, after which cell death was assessed by 7-AAD. (PPTX $172 \mathrm{~kb}$ )

Additional file 2: The caspase inhibitor BOC-D-fmk does not change HHT/ Bort-mediated down-regulation of MCL-1. OCI-LY18 and Carnaval cells were treated with $\mathrm{HHT}+$ Bort for $24 \mathrm{~h}$ either in the absence or presence of $5 \mu \mathrm{mol} / \mathrm{L}$ BOC-D-fmk. At the end of this period, cells were lysed and subjected to Western blot analysis using the indicated primary antibodies. Each lane was loaded with $25 \mu \mathrm{g}$ of protein. Blots were stripped and reprobed with antitubulin antibodies to ensure equal loading and transfer of protein. Representative of two separate experiments. (PPTX $100 \mathrm{~kb}$ )

Additional file 3: HHT inhibits MCL-1 expression through a post-transcriptional mechanism. A. SU-DHL4 and SU-DHL16 cells were treated with HHT for $8 \mathrm{~h}$ after which cells were lysed and proteins extracted. Expression of the indicated proteins was determined by Western blotting using the indicated antibodies. B. SU-DHL4 and SU-DHL16 cells were treated with HHT for $8 \mathrm{~h}$ after which cells were extracted for mRNA. Relative levels of MCL-1 mRNA/GAPDH were calculated. C. SU-DHL4 and SU-DHL16 cells were pre-treated with actinomycin $(2.5 \mu \mathrm{g} / \mathrm{ml}$ ) for $30 \mathrm{~min}$ and then exposed to HHT $2 \mathrm{~h}$ (SU-DHL4 $60 \mathrm{nM}$,
SU-DHL16 20 nM) after which cells were lysed and proteins extracted. Expression of the indicated proteins was determined by western blott using the indicated antibodies. D. SU-DHL4 and SU-DHL16 cells were pre-treated with cyclohexamide $(5 \mu \mathrm{g} / \mathrm{ml})$ for $30 \mathrm{~min}$ and then exposed to HHT $2 \mathrm{~h}$ and $4 \mathrm{~h}$ (SU-DHL4 60 nM, SU-DHL16 20 nM) after which cells were lysed and proteins extracted. Expression of the indicated proteins was determined by western blot. (PPTX $236 \mathrm{~kb}$ )

Additional file 4: Co-treatment with HHT and bortezomib does not cause significant weight loss in NSG mice. A. Weights of each mouse in the flank model study (SU-DHL-4) were monitored twice a week, and the mean weights for each group were plotted against days of treatment $(p>0.05=$ no significant difference for combination group values compared to single-agent treatment or controls). B. Weights of each mouse in the systemic model study (U2932) were monitored twice a week and the mean weights for each group were plotted against days of treatment $(p>0.05=$ no significant differences were noted for the combination group values compared to single-agent treatment or the control group. (PPTX $134 \mathrm{~kb}$ )

\section{Abbreviations}

DLBCL: Diffuse large B cell lymphoma; HHT: Homoharringtonine;

MCL: Mantle cell lymphoma; NHL: Non-Hodgkin lymphoma

\section{Acknowledgments}

This work was supported by awards CA205607 and CA167708 from the NCl, award \#6472-15 from the Leukemia and Lymphoma Society of America, and an award from Teva Pharmaceutical Industries Ltd. We gratefully acknowledge Dr Hisashi Harada for providing the NOXA/FLAG construct.

\section{Availability of data and materials}

The data generated in this study are available in the Additional files for this manuscript.

\section{Authors' contributions}

TN and SG developed, designed the study and wrote the manuscript. TN, RP, YZ, EH, MK, WC performed experiments and assisted data analysis. All authors read and approved the final manuscript.

Ethics approval and consent to participate

This study was approved by the ethics committee of Virginia Commonwealth University (VCU). Patients signed a written informed consent form. Animal studies were conducted under protocol (AD20191) approved by VCU's Institutional animal care and use committee (IACUC).

\section{Consent for publication}

Not applicable.

\section{Competing interests}

The authors declare that they have no competing interests.

\section{Publisher's Note}

Springer Nature remains neutral with regard to jurisdictional claims in published maps and institutional affiliations.

\section{Author details}

${ }^{1}$ Division of Hematology/Oncology, Virginia Commonwealth University Richmond, Room 229 Goodwin Research Building, 401 College Street, Richmond, VA 23229, USA. Palliative Care, Virginia Commonwealth University Richmond, Richmond, VA, USA. '3 Department of Biochemistry, Virginia Commonwealth University Richmond, Richmond, VA, USA. ${ }^{4}$ Human and Molecular Genetics, Virginia Commonwealth University Richmond, Richmond, VA, USA. ${ }^{5}$ Massey Cancer Center, Virginia Commonwealth University Richmond, Richmond, VA, USA.

Received: 5 April 2018 Accepted: 30 October 2018 Published online: 16 November 2018

\section{References}

1. Shankland KR, Armitage JO, Hancock BW. Non-Hodgkin Iymphoma. Lancet. 2012;380(9844):848-57. 
2. Honigberg LA, Smith AM, Sirisawad M, Verner E, Loury D, Chang B, Li S, Pan Z, Thamm DH, Miller RA, et al. The Bruton tyrosine kinase inhibitor PCl32765 blocks B-cell activation and is efficacious in models of autoimmune disease and B-cell malignancy. Proc Natl Acad Sci U S A. 2010;107(29): 13075-80.

3. Wang ML, Rule S, Martin P, Goy A, Auer R, Kahl BS, Jurczak W, Advani RH, Romaguera JE, Williams ME, et al. Targeting BTK with ibrutinib in relapsed or refractory mantle-cell lymphoma. N Engl J Med. 2013;369(6):507-16.

4. Hu S, Xu-Monette ZY, Tzankov A, Green T, Wu L, Balasubramanyam A, Liu WM, Visco C, Li Y, Miranda RN, et al. MYC/BCL2 protein coexpression contributes to the inferior survival of activated B-cell subtype of diffuse large B-cell lymphoma and demonstrates high-risk gene expression signatures: a report from the international DLBCL rituximab-CHOP consortium program. Blood. 2013;121(20):4021-31 quiz 4250.

5. Visco C, Tzankov A, Xu-Monette ZY, Miranda RN, Tai YC, Li Y, Liu WM, d'Amore ES, Li Y, Montes-Moreno S, et al. Patients with diffuse large B-cell lymphoma of germinal center origin with BCL2 translocations have poor outcome, irrespective of MYC status: a report from an international DLBCL rituximabCHOP consortium program study. Haematologica. 2013;98(2):255-63.

6. Thieblemont C, Briere J. MYC, BCL2, BCL6 in DLBCL: impact for clinics in the future? Blood. 2013;121(12):2165-6.

7. Cheah CY, Seymour JF, Wang ML. Mantle cell lymphoma. J Clin Oncol Off J Am Soc Clin Oncol. 2016;34(11):1256-69.

8. O'Connor OA. Marked clinical activity of the proteasome inhibitor bortezomib in patients with follicular and mantle-cell lymphoma. Clin Lymphoma Myeloma. 2005;6(3):191-9.

9. Bose P, Batalo MS, Holkova B, Grant S. Bortezomib for the treatment of nonHodgkin's lymphoma. Expert Opin Pharmacother. 2014;15(16):2443-59.

10. Leonard JP, Kolibaba KS, Reeves JA, Tulpule A, Flinn IW, Kolevska T, Robles R, Flowers CR, Collins R, DiBella NJ, et al. Randomized Phase II Study of RCHOP With or Without Bortezomib in Previously Untreated Patients With Non-Germinal Center B-Cell-Like Diffuse Large B-Cell Lymphoma. J Clin Oncol Off J Am Soc Clin Oncol. 2017;35:3538-46.

11. Nencioni A, Hua F, Dillon CP, Yokoo R, Scheiermann C, Cardone MH, Barbieri E, Rocco I, Garuti A, Wesselborg S, et al. Evidence for a protective role of $\mathrm{mcl}-1$ in proteasome inhibitor-induced apoptosis. Blood. 2005;105(8):3255-62.

12. Chen R, Guo L, Chen Y, Jiang Y, Wierda WG, Plunkett W. Homoharringtonine reduced mcl-1 expression and induced apoptosis in chronic lymphocytic leukemia. Blood. 2011;117(1):156-64.

13. Gandhi V, Plunkett W, Cortes JE. Omacetaxine: a protein translation inhibitor for treatment of chronic myelogenous leukemia. Clin Can Res. 2014;20(7):1735-40.

14. Quintas-Cardama A, Kantarjian H, Cortes J. Homoharringtonine, omacetaxine mepesuccinate, and chronic myeloid leukemia circa 2009. Cancer. 2009; 115(23):5382-93.

15. Alvandi F, Kwitkowski VE, Ko CW, Rothmann MD, Ricci S, Saber H, Ghosh D, Brown J, Pfeiler E, Chikhale E, et al. U.S. Food and Drug Administration approval summary: omacetaxine mepesuccinate as treatment for chronic myeloid leukemia. Oncologist. 2014;19(1):94-9.

16. Allan EK, Holyoake TL, Craig AR, Jorgensen HG. Omacetaxine may have a role in chronic myeloid leukaemia eradication through downregulation of mcl-1 and induction of apoptosis in stem/progenitor cells. Leukemia. 2011; 25(6):985-94.

17. Kuroda J, Kamitsuji Y, Kimura S, Ashihara E, Kawata E, Nakagawa Y, Takeuichi M, Murotani Y, Yokota A, Tanaka $R$, et al. Anti-myeloma effect of homoharringtonine with concomitant targeting of the myeloma-promoting molecules, mcl-1, XIAP, and beta-catenin. Int J Hematol. 2008;87(5):507-15.

18. Kantarjian H, O'Brien S, Jabbour E, Barnes G, Pathak A, Cortes J. Effectiveness of homoharringtonine (omacetaxine mepesuccinate) for treatment of acute myeloid leukemia: a meta-analysis of Chinese studies. Clin Lymphoma Myeloma Leuk. 2015;15(1):13-21.

19. Hu J, Dang N, Menu E, De Bruyne E, Xu D, Van Camp B, Van Valckenborgh E, Vanderkerken K. Activation of ATF4 mediates unwanted mcl-1 accumulation by proteasome inhibition. Blood. 2012;119(3):826-37.

20. Chen $P$, Yuan $Q$, Yang $H$, Wen $X$, You $P$, Hou D, Xie J, Cheng Y, Huang $H$. Homoharringtonine enhances bortezomib antimyeloma activity in myeloma cells adhesion to bone marrow stromal cells and in SCID mouse xenografts. Leuk Res. 2017;57:119-26.

21. Nguyen T, Parker R, Hawkins E, Holkova B, Yazbeck V, Kolluri A, Kmieciak M, Rahmani M, Grant S. Synergistic interactions between PLK1 and HDAC inhibitors in non-Hodgkin's lymphoma cells occur in vitro and in vivo and proceed through multiple mechanisms. Oncotarget. 2017;8(19):31478-93.
22. Nguyen TK, Grant S. Dinaciclib (SCH727965) inhibits the unfolded protein response through a CDK1- and 5-dependent mechanism. Mol Cancer Ther. 2014;13(3):662-74.

23. Nakajima W, Sharma K, Lee JY, Maxim NT, Hicks MA, Vu TT, Luu A, Yeudall WA, Tanaka N, Harada H. DNA damaging agent-induced apoptosis is regulated by MCL-1 phosphorylation and degradation mediated by the Noxa/MCL-1/CDK2 complex. Oncotarget. 2016;7(24):36353-65.

24. Nguyen T, Dai Y, Attkisson E, Kramer L, Jordan N, Nguyen N, Kolluri N, Muschen M, Grant S. HDAC inhibitors potentiate the activity of the BCR/ $A B L$ kinase inhibitor KW-2449 in imatinib-sensitive or -resistant BCR/ABL+ leukemia cells in vitro and in vivo. Clin Can Res. 2011;17(10):3219-32.

25. Klanova M, Andera L, Brazina J, Svadlenka J, Benesova S, Soukup J, Prukova D, Vejmelkova D, Jaksa R, Helman K, et al. Targeting of BCL2 family proteins with ABT-199 and Homoharringtonine reveals BCL2- and MCL1-dependent subgroups of diffuse large B-cell lymphoma. Clin Cancer Res. 2016;22(5): $1138-49$.

26. Hambley B, Caimi PF, William BM. Bortezomib for the treatment of mantle cell lymphoma: an update. Therapeutic Adv Hematol. 2016;7(4):196-208.

27. Mitra P, Yang RM, Sutton J, Ramsay RG, Gonda TJ. CDK9 inhibitors selectively target estrogen receptor-positive breast cancer cells through combined inhibition of MYB and MCL-1 expression. Oncotarget. 2016;7(8): 9069-83.

28. Yeh $Y Y$, Chen R, Hessler J, Mahoney E, Lehman AM, Heerema NA, Grever MR, Plunkett W, Byrd JC, Johnson AJ. Up-regulation of CDK9 kinase activity and mcl-1 stability contributes to the acquired resistance to cyclindependent kinase inhibitors in leukemia. Oncotarget. 2015;6(5):2667-79.

29. Chen R, Keating MJ, Gandhi V, Plunkett W. Transcription inhibition by flavopiridol: mechanism of chronic lymphocytic leukemia cell death. Blood. 2005;106(7):2513-9.

30. Lucas DM, Edwards RB, Lozanski G, West DA, Shin JD, Vargo MA, Davis ME, Rozewski DM, Johnson AJ, Su BN, et al. The novel plant-derived agent silvestrol has B-cell selective activity in chronic lymphocytic leukemia and acute lymphoblastic leukemia in vitro and in vivo. Blood. 2009;113(19): 4656-66.

31. Tang R, Faussat AM, Majdak P, Marzac C, Dubrulle S, Marjanovic Z, Legrand O, Marie JP. Semisynthetic homoharringtonine induces apoptosis via inhibition of protein synthesis and triggers rapid myeloid cell leukemia-1 down-regulation in myeloid leukemia cells. Mol Cancer Ther. 2006;5(3):723-31.

32. Williams SA, McConkey DJ. The proteasome inhibitor bortezomib stabilizes a novel active form of p53 in human LNCaP-Pro5 prostate cancer cells. Cancer Res. 2003;63(21):7338-44.

33. Ding WX, Ni HM, Chen X, Yu J, Zhang L, Yin XM. A coordinated action of Bax, PUMA, and p53 promotes MG132-induced mitochondria activation and apoptosis in colon cancer cells. Mol Cancer Ther. 2007;6(3):1062-9.

34. Baou M, Kohlhaas SL, Butterworth M, Vogler M, Dinsdale D, Walewska R, Majid A, Eldering E, Dyer MJ, Cohen GM. Role of NOXA and its ubiquitination in proteasome inhibitor-induced apoptosis in chronic lymphocytic leukemia cells. Haematologica. 2010;95(9):1510-8.

35. Rizzatti EG, Mora-Jensen H, Weniger MA, Gibellini F, Lee E, Daibata M, Lai R, Wiestner A. Noxa mediates bortezomib induced apoptosis in both sensitive and intrinsically resistant mantle cell lymphoma cells and this effect is independent of constitutive activity of the AKT and NF-kappaB pathways. Leuk Lymphoma. 2008;49(4):798-808.

36. Gomez-Bougie P, Wuilleme-Toumi S, Menoret E, Trichet V, Robillard N, Philippe M, Bataille R, Amiot M. Noxa up-regulation and mcl-1 cleavage are associated to apoptosis induction by bortezomib in multiple myeloma. Cancer Res. 2007:67(11):5418-24.

37. Nakajima W, Hicks MA, Tanaka N, Krystal GW, Harada H. Noxa determines localization and stability of MCL-1 and consequently ABT-737 sensitivity in small cell lung cancer. Cell Death Dis. 2014;5:e1052.

38. Oda E, Ohki R, Murasawa H, Nemoto J, Shibue T, Yamashita T, Tokino T, Taniguchi T, Tanaka N. Noxa, a BH3-only member of the Bcl-2 family and candidate mediator of p53-induced apoptosis. Science. 2000;288(5468): 1053-8.

39. Ploner C, Kofler R, Villunger A. Noxa: at the tip of the balance between life and death. Oncogene. 2008;27(Suppl 1):S84-92.

40. Busacca S, Chacko AD, Klabatsa A, Arthur K, Sheaff M, Barbone D, Mutti L, Gunasekharan VK, Gorski JJ, El-Tanani M, et al. BAK and NOXA are critical determinants of mitochondrial apoptosis induced by bortezomib in mesothelioma. PLoS One. 2013;8(6):e65489. 
41. Willis SN, Chen L, Dewson G, Wei A, Naik E, Fletcher Jl, Adams JM, Huang DC. Proapoptotic Bak is sequestered by $\mathrm{mcl}-1$ and $\mathrm{BCl}-\mathrm{xL}$, but not $\mathrm{BCl}-2$, unti displaced by BH3-only proteins. Genes Dev. 2005;19(11):1294-305.

42. Nemunaitis J, Mita A, Stephenson J, Mita MM, Sarantopoulos J,

Padmanabhan-lyer S, Nanda N, Gleich L, Benichou AC, Craig A.

Pharmacokinetic study of omacetaxine mepesuccinate administered

subcutaneously to patients with advanced solid and hematologic tumors.

Cancer Chemother Pharmacol. 2013;71(1):35-41.

Ready to submit your research? Choose BMC and benefit from:

- fast, convenient online submission

- thorough peer review by experienced researchers in your field

- rapid publication on acceptance

- support for research data, including large and complex data types

- gold Open Access which fosters wider collaboration and increased citations

- maximum visibility for your research: over $100 \mathrm{M}$ website views per year

At $B M C$, research is always in progress.

Learn more biomedcentral.com/submissions 